\title{
Tablet Dosing Unit
}

National Cancer Institute

\section{Source}

National Cancer Institute. Tablet Dosing Unit. NCI Thesaurus. Code C48542.

A dosing unit equal to the amount of active ing redient(s) contained in a tablet. 